\title{
The copepod assemblage (Copepoda: Crustacea) on the inner continental shelf adjacent to Camamu Bay, northeast Brazil
}

\author{
Cristina de Oliveira Dias ${ }^{1,2} \&$ Sérgio Luiz Costa Bonecker ${ }^{1}$
}

\author{
1 Universidade Federal do Rio de Janeiro, Instituto de Biologia, Departamento de Zoologia, Laboratório Integrado de \\ Zooplâncton e Ictioplâncton. Bloco A, Cidade Universitária, 21941-590 Rio de Janeiro, Rio de Janeiro, Brasil. \\ 2 Corresponding author. E-mail: crcldias@hotmail.com
}

\begin{abstract}
The copepod assemblage on the inner continental shelf adjacent to the coastal system of Camamu Bay (state of Bahia, Brazil) is described in relation to hydrographic conditions, during the wet and dry seasons of 2004. The zooplankton samples were obtained in vertical tows using a net with $200 \mu \mathrm{m}$ mesh size. Temperature and salinity were measured, and the total density, frequency and percentage occurrence of the copepod taxa were determined for each sampling period. The highest densities were observed at the entrance of Camamu Bay (up to 7.473 ind. $\mathrm{m}^{-3}$ ), and the lowest on the adjacent inner continental shelf south of Camamu Bay (less than 500 ind. $\mathrm{m}^{-3}$ ). A total of 57 copepod taxa were identified. Paracalanus quasimodo Bowman, 1971, Subeucalanus pileatus (Giesbrecht, 1888), Clausocalanus furcatus (Brady, 1883), Corycaeus giesbrechti F. Dahl, 1894, Temora turbinata (Dana, 1849), Oithona similis Claus, 1866, Temora stylifera (Dana, 1849) and Nannocalanus minor (Claus, 1863) dominated numerically. The densities measured in both sampling seasons were significantly different: the means were $1.849 \pm 1.922$ ind. $\mathrm{m}^{-3}$ and $3.657 \pm 3.170$ ind. $\mathrm{m}^{-3}$ for the wet season and dry season, respectively. Depth and temporal variation in temperature and salinity influenced species abundance during the wet and dry seasons, with the dominant species alternating. Species richness and diversity increased on the inner shelf adjacent to the coastal system of Camamu Bay at the 30- and 50-m isobaths, suggesting that most species were oceanic in origin. The diversity was similar to other coastal systems of northeast Brazil.
\end{abstract}

KEY WORDS. Coastal region; spatial-temporal variation; tropical zone; zooplankton.

The Camamu-Almada basin is located on the northeast coast of Brazil, on the south coast of the state of Bahia. It is also known as the Cocoa Coast near the municipality of Ilhéus, and as the Dendê Coast near the municipalities of Camamu, Nilo Peçanha, Ituberá and Salvador. The main source of income in the region involves the exploration of natural resources, of which small-scale fishery is one of the most important (Souza \& Petrere-Jr 2008). Much of the coast is extremely indented, with innumerable islands, several estuaries and the large Camamu Bay (Milani et al. 2000).

Camamu Bay is the third largest bay in Brazil that allows traffic of ships, exceeded only by the Todos os Santos and Guanabara bays. Camamu Bay is surrounded by an extensive mangrove forest, more than $40 \mathrm{~km}^{2}$ in area. The bay is of great economic importance in the southern part of the northeast coast of Brazil, because of its primary production, supplying fish for local consumption and commercial sale, and also mining and tourist areas (de Oliveira et al. 2002, Lima 2003).

The plankton of ocean environments is unevenly distributed ('patchy'), and the importance of spatial heterogeneity to plankton ecology is well recognized. Plankton communities are often structured in assemblages with a close relation- ship to environmental characteristics. The distribution of water masses and currents constitutes the basis for the interpretation of plankton distributional patterns (BERASATEGUi et al. 2006).

Investigations on epipelagic copepods off Brazil, reviewed by BRANDINI et al. (1997), began at the end of the 1900s. BJÖRNBERG (1963) provided the first detailed account on the communities of epipelagic species in relation to the distribution of water masses. Few zooplankton surveys have been carried out on the continental shelf off northern Bahia (NeumanN-LeITÃo 1995). Björnberg (1963), Gaudy (1963), Seguin (1965) and Valentin \& Monteiro-Ribas (1993) studied the region between Todos os Santos Bay and Abrolhos Bank. The southern part of the northeast coast of Brazil is among the areas of the Brazilian coast with the fewest studies published on the estuarine and coastal zooplankton communities (NEUMANN-LeITÃo 1995). Until the end of the 2000s, only dissertations, theses and the works of SANTOS (1973) and Peixinho et al. (1980), in Todos os Santos Bay, and SCHWAMBORN \& BONECKER (1996), in the estuary of the Mucuri River, had been published. Recently, Madureira et al. (2004) and Dias \& Bonecker $(2006,2007)$ carried out studies in this area.

Copepods are among the most numerous multicellular organisms, and are one of the keystone trophic links in aquatic 
ecosystems. They are well represented in terms of species richness in all aquatic environments (BerASATEgui et al. 2006). However, copepod communities of the coastal region of Camamu Bay and the adjacent inner continental shelf have never been analyzed together.

In tropical oceans, community seasonal dynamics are difficult to identify and are much less marked than those in temperate aquatic ecosystems. The seasonal variations recorded in tropical and subtropical coastal regions are mainly determined by the local influence of the rainy and dry seasons and by regional oceanographic phenomena. These phenomena derive from singular or irregular events, in contrast to those in temperate and polar seas, where the variations of biomass during the year are more predictable (NyBAKKEn \& BERTNEss 2005).

The aim of this study was to describe the occurrence, patterns of abundance and the copepod assemblage on the inner shelf near Camamu Bay (Bahia, Brazil) as a function of depth, from data gathered over two seasons (wet and dry season 2004). The results were compared with others in different coastal regions. The relationships of the copepods with environmental factors were also examined.

\section{MATERIAL AND METHODS}

The Camamu-Almada Basin, located on the coast of the south-central region of Bahia State, occupies an area of 22,900 $\mathrm{km}^{2}$ up to the 3,000 $\mathrm{m}$ isobath. Its southern limit is the Jequitinhonha Basin, through the Alto de Olivença, and its northern limit lies at the Jacuípe Basin and the Recôncavo, through the transfer areas of Itapoá and Barra, respectively. The Camamu Basin, to the north, is separated from the Almada Basin by the Alto de Taipús (Souza \& Petrere-Jr 2008).

The climate of this region is humid tropical, with three dry months during the year (August, September and October). May is the wettest month, with a mean precipitation of $8.3 \mathrm{~mm}$ per day. September is the driest month, with a mean precipitation of $2.6 \mathrm{~mm}$ per day. The temperature varies from $23.7^{\circ} \mathrm{C}$ in the winter to $26.7^{\circ} \mathrm{C}$ during the summer (Souza \& Petrere-JR 2008).

The study area contains a great diversity of ecosystems, such as sandbanks, beaches, mangroves, reefs, and gravel and mud bottoms. Each of these habitats possesses unique faunal and vegetation characteristics. Mangroves occupy the river margins, especially on the Boipeba and Tinharé islands, but also occur in other areas along the estuary. Some mangroves and sandbank areas showed signs of human occupation. This occupation allows some economic activities such as marine culture, but it also increases pollution from domestic waste (Souza \& Petrere-Jr 2008).

Camamu Bay is a tropical estuary in the Camamu-Almada basin. The bay is located between Garapuá $\left(13^{\circ} 48.3^{\prime} \mathrm{S}\right.$, $\left.38^{\circ} 91.7^{\prime} \mathrm{W}\right)$ and Maraú peninsula $\left(14^{\circ} 10.0^{\prime} \mathrm{S}, 39^{\circ} \mathrm{W}\right), 335 \mathrm{~km}$ south of the city of Salvador, in the state of Bahia. The bay is irregular, and contains numerous islands, the largest being Grande and Pequena islands in its center. This large body of water is surrounded by an extensive mangrove forest that occupies more than $40 \mathrm{~km}^{2}$ (DE Oliveira et al. 2002).

The local population is dependent on the natural resources. The economic activity on the coast and its area of influence is diversified, ranging from mining to chemical and energy industries, extensive cattle ranches, and tourism. Cellulose, oil and natural gas, tourism, marine calcareous rock mining, and fishery and forestry industries all have high potential to impact the bay and adjacent ocean systems (Milani et al. 2000).

Sampling was carried out in the wet season, from 15 to 20 January 2004 during ebb and flood tide, and in the dry season, from 26 to 28 August 2004 during flood tide. Zooplankton samples were collected at 11 stations distributed along five transects perpendicular to the coast, located at the isobaths of $10 \mathrm{~m}$ (stations 2, 5, and 8), $30 \mathrm{~m}$ (stations 1, 3, 6, 9 and 11) and $50 \mathrm{~m}$ (stations 4, 7 and 10) (Fig. 1). Rainfall data were made available by Dr. Andrelina L. dos Santos of the Agência Nacional de Águas (ANA).

The samples were collected during the day, by vertical hauls with a conical net of mesh size $200 \mu \mathrm{m}$ and mouth diameter 60 $\mathrm{cm}$, fitted with a calibrated flowmeter. Samples were preserved in $4 \%$ buffered formalin. The samples were divided into fractions with a Folsom Plankton Sample Splitter (McEwEN et al. 1957), and replicated subsamples containing at least 100 individuals were taken for analysis (FronTIER 1981). Copepods were identified to species level whenever possible, according to Björnberg (1981), BradFord-Grieve et al. (1999) and Dias \& Araujo (2006). Species composition and abundance were determined for all samples. Adults and copepodites were included in estimations of the total density of each species. The abundances were expressed as number of individuals per cubic meter (ind. $\mathrm{m}^{-3}$ ). Shannon's diversity index (SHANNON 1948) was calculated to evaluate the degree of organization of the copepod community, and evenness was calculated according to PIELOU (1977).

All the specimens were deposited in the copepod collection of the Integrated Zooplankton and Ichthyoplankton Laboratory of the Federal University of Rio de Janeiro.

Water temperature and salinity were also determined, using a Hydrolab CTD (Quanta). Two depths were chosen in order to analyze these parameters: at the surface $(0.5 \mathrm{~m})$ and near the bottom $(0.5 \mathrm{~m}$ above the bottom), which cover the area sampled by net.

The paired-sample Student's t test was used to determine statistical differences between the two sample series (wet and dry season). Analysis of variance (ANOVA) was used at a significance level of $\mathrm{p}=0.05$ to identify statistical differences among the sampling stations and between the sampling periods. All data were evaluated for normality and homogeneity prior to analysis. The post-hoc test was used to identify the differences among the collections when statistical differences were found.

A multivariate numerical classification technique was used to classify stations into groups with different copepod community structure. The species-by-sampling-site matrix, for species 


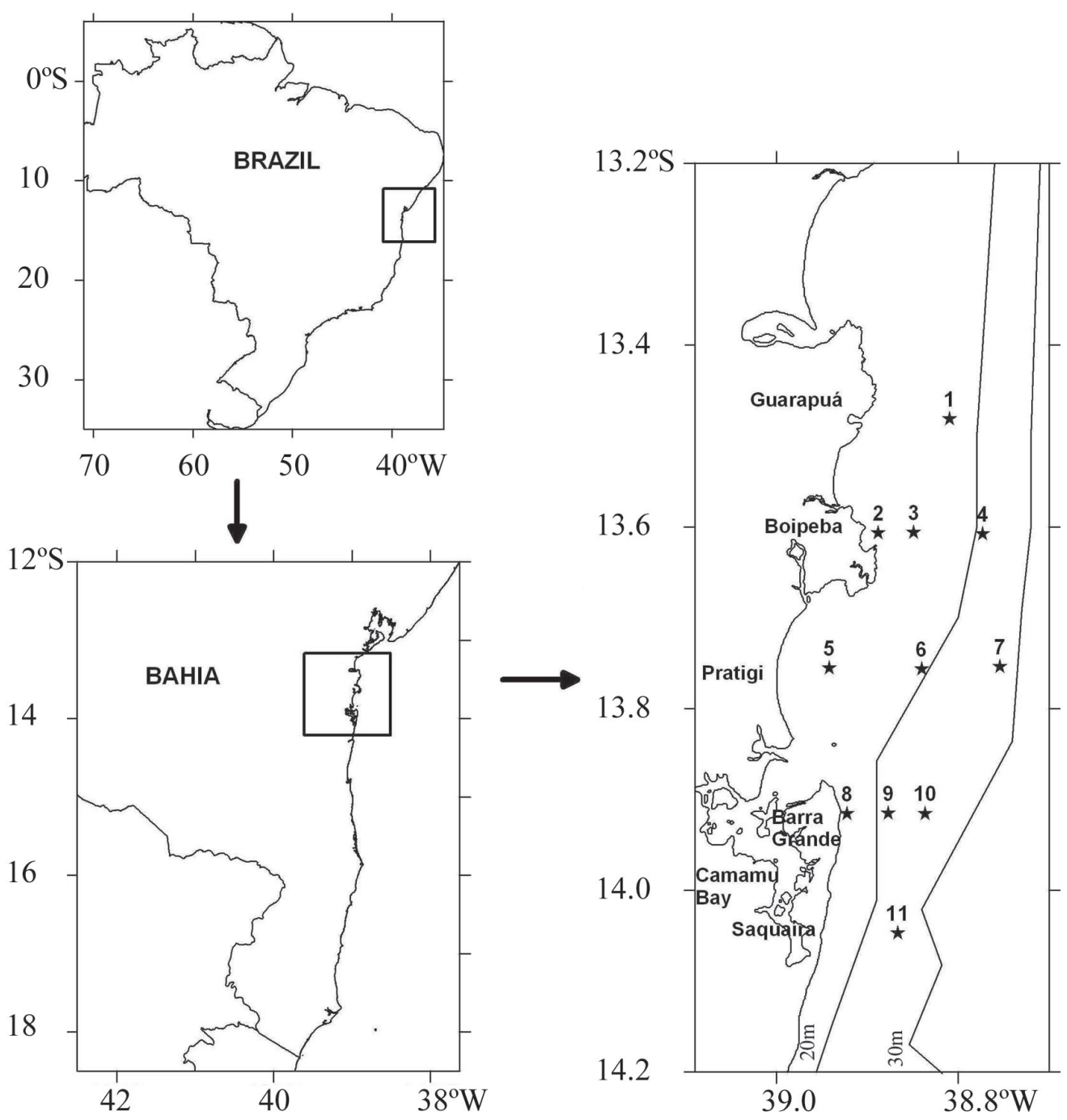

Figure 1. Sampling locations on the inner shelf adjacent to the coastal system of Camamu Bay.

with occurrences higher than 5\%, was analyzed using cluster analysis (CLARKE \& WARWICK 1994). Hierarchical agglomerative clustering was carried out using the Bray-Curtis similarity index coupled with group average linkage, to produce a dendrogram depicting clusters of stations based on their biological composition. This technique has proved appropriate for delineating groups with distinct community structure in a large number of ecological studies (Clarke \& WarWICK 1994). Analysis of similarity (ANOSIM) was used to test if the sampling year showed significant differences in its copepod assemblage structure. The SIMPER test (similarity percentages) was then used to identify the species that most contributed to similarities within groups.

Correlation between the total copepod density and environmental variables (temperature and salinity at the surface and near the bottom) was estimated using the Pearson $r$-index.

\section{RESULTS}

\section{Environmental data}

Three water masses were recognized on the inner shelf adjacent to the coastal system of Camamu Bay: Tropical Water (TW - temperatures $>20.0^{\circ} \mathrm{C}$ and salinities $>36.0$ ), Mixed Water (MW - temperatures $>20.0^{\circ} \mathrm{C}$ and salinities from 34.5 to 36.0), and Coastal Water (CW - temperatures $>20.0^{\circ} \mathrm{C}$ and salinities $<34.5$ ) (Tab. I). The Mixed Water (MW) is the result of mixing of the Tropical Water (TW) and continental drainage (Coastal Water - CW).

The hydrographic parameters differed between the cruises (wet and dry season 2004). Analyzing the depths, during the wet season the highest temperatures and the lowest salinities were recorded, with a mean temperature at the surface of 
$26.97^{\circ} \mathrm{C}$ (S.D.: 0.33 ), and near the bottom of $26.25^{\circ} \mathrm{C}$ (S.D.: $0.68)$. The mean salinity in this season at the surface was 33.33 (S.D.: 2.41), and near the bottom was 33.46 (S.D.: 3.05). These values are related to the presence of the $\mathrm{CW}$ in the stations located at the entrance of Camamu Bay and the adjacent inner shelf (up to 50-m isobath), during an ebb-flood and flood tide, with the exception of stations 2 and 7 (Tab. I). This may also be associated with precipitation during this season $(161.9 \mathrm{~mm})$. In the dry season, the presence of the MW and TW was observed at all stations of the study area, with a rainfall of 21.5 $\mathrm{mm}$. The mean temperature at the surface was $25.33^{\circ} \mathrm{C}$ (S.D.: 0.39 ) and near the bottom was $24.96^{\circ} \mathrm{C}$ (S.D.: 0.23). The mean salinity was 35.46 (S.D.: 0.19) at the surface, and 36.23 (S.D.: 0.30) near the bottom. In this season, all samples were taken during the flood tide.

Based on ANOVA $(\mathrm{p}<0.05)$, water temperature differed among the samples taken in the two depths. During the survey period, water temperature was highest at the surface during both cruises. Water temperature ranged between $26.3^{\circ} \mathrm{C}$ (station 8) and $27.3^{\circ} \mathrm{C}$ (station 2) at the surface, and $25.3^{\circ} \mathrm{C}$ (station 4 ) and $27.7^{\circ} \mathrm{C}$ (station 11) near the bottom in the wet season. During the dry season, water temperature ranged between $25^{\circ} \mathrm{C}$ (stations 1,8 and 9 ) and $26.3^{\circ} \mathrm{C}$ (station 2) at the surface, and $24.4^{\circ} \mathrm{C}$ (station 4 ) and $25.2^{\circ} \mathrm{C}$ (stations 5 and 8) near the bottom (Tab. I).

Salinity was lower at the surface than near the bottom during both cruises. During the wet season, salinity varied less widely between the stations at the surface (6.9) than near the bottom (10.6). In general, the higher salinities (Tropical Water, TW > 36) were found in the north (station 1 at the surface, station 2 at both depths and station 4 near the bottom) and the south (station 11 at the surface) of Camamu Bay. Water salinity was homogeneous during the dry season, when it ranged between 35.2 (stations 1 and 5) and 35.8 (station 11) at the surface, and between 35.5 (station 5) and 36.6 (station 4) near the bottom (Tab. I).

Table I. Temperature $\left({ }^{\circ} \mathrm{C}\right)$, salinity and water-mass classification during the wet and dry season of 2004 on the inner continental shelf adjacent to the coastal system of Camamu Bay.

\begin{tabular}{|c|c|c|c|c|c|c|}
\hline & \multicolumn{3}{|c|}{ Surface } & \multicolumn{3}{|c|}{ Bottom } \\
\hline & Temp. $\left({ }^{\circ} \mathrm{C}\right)$ & Salinity & Water-mass & Temp. $\left({ }^{\circ} \mathrm{C}\right)$ & Salinity & Water-mass \\
\hline \multicolumn{7}{|c|}{ Wet Season (Jan/2004) } \\
\hline 1 & 27.0 & 36.1 & TW & 25.9 & 31.6 & $\mathrm{CW}$ \\
\hline 2 & 27.3 & 36.3 & TW & 27.0 & 36.8 & TW \\
\hline 3 & 27.2 & 31.9 & $\mathrm{CW}$ & 26.1 & 33.6 & $\mathrm{CW}$ \\
\hline 4 & 27.3 & 29.4 & $\mathrm{CW}$ & 25.3 & 36.3 & TW \\
\hline 5 & 27.1 & 33.0 & CW & 26.5 & 35.6 & MW \\
\hline 6 & 27.1 & 30.7 & $\mathrm{CW}$ & 26.0 & 26.2 & CW \\
\hline 7 & 27.2 & 35.4 & MW & 25.7 & 35.6 & MW \\
\hline 8 & 26.3 & 31.4 & CW & 26.1 & 31.1 & CW \\
\hline 9 & 26.9 & 32.3 & $\mathrm{CW}$ & 26.7 & 33.7 & $\mathrm{CW}$ \\
\hline 10 & 26.8 & 34.0 & CW & 25.7 & 35.0 & MW \\
\hline 11 & 26.5 & 36.1 & TW & 27.7 & 32.6 & CW \\
\hline \multicolumn{7}{|c|}{ Dry Season (Aug/2004) } \\
\hline 1 & 25.0 & 35.2 & MW & 25.0 & 36.3 & TW \\
\hline 2 & 26.3 & 35.3 & MW & 25.1 & 35.9 & MW \\
\hline 3 & 25.4 & 35.5 & MW & 25.0 & 36.2 & TW \\
\hline 4 & 25.1 & 35.5 & MW & 24.4 & 36.6 & TW \\
\hline 5 & 25.7 & 35.2 & MW & 25.2 & 35.5 & MW \\
\hline 6 & 25.4 & 35.6 & MW & 24.8 & 36.3 & TW \\
\hline 7 & 25.1 & 35.4 & MW & 25.1 & 36.4 & TW \\
\hline 8 & 25.0 & 35.5 & MW & 25.2 & 36.5 & TW \\
\hline 9 & 25.0 & 35.4 & MW & 24.8 & 36.2 & TW \\
\hline 10 & 25.3 & 35.7 & MW & 25.0 & 36.3 & TW \\
\hline 11 & 25.3 & 35.8 & MW & 25.0 & 36.3 & TW \\
\hline
\end{tabular}




\section{The copepod assemblages}

Copepods were the predominant group of zooplankton in the study area in terms of species diversity and numerical abundance, comprising $92 \%$ of the total zooplankton. Total density of copepods was significantly higher during the dry season ( $\mathrm{p}<0.05$ ). In the wet season, the maximum copepod abundance was 7.473 ind. $\mathrm{m}^{-3}$ at station 8, near Barra Grande at the entrance of Camamu Bay, and the lowest was below 800 ind. $\mathrm{m}^{-3}$ at stations 7 and 11, in the adjacent inner shelf (Figs 2 and 3). The mean abundance of copepods was 1.849 ind. $\mathrm{m}^{-3}$ (S.D. 1.922). The highest abundance of copepods in the dry season was 11.260 ind. $\mathrm{m}^{-3}$ at station 8 , and the next was 6.792 ind. $\mathrm{m}^{-3}$ and 6.044 ind. $\mathrm{m}^{-3}$ at stations 3 and 11, respectively, on the adjacent inner shelf. The lowest abundance was 929 ind. $\mathrm{m}^{-3}$ collected at Pratigi (station 5) near Camamu Bay (Figs 2 and 3). The mean abundance was 3.657 ind. $\mathrm{m}^{-3}$ (S.D. 3,170) in the dry season.

A total of 57 copepod taxa were identified (Tab. II), of which 12 species occurred in more than $50 \%$ of the samples, whereas 15 were found in less than 10\%. The assemblage was dominated by eight species: Paracalanus quasimodo Bowman, 1971, Subeucalanus pileatus (Giesbrecht, 1888), Clausocalanus furcatus (Brady, 1883), Corycaeus giesbrechti F. Dahl, 1894, Temora turbinata (Dana, 1849), Oithona similis Claus, 1866, Temora stylifera (Dana, 1849) and Nannocalanus minor (Claus, 1863) during the entire sampling period (Figs 4-11). The zooplankton composition was relatively homogeneous, with these species constituting more than $55 \%$ of the total density during both sampling periods.
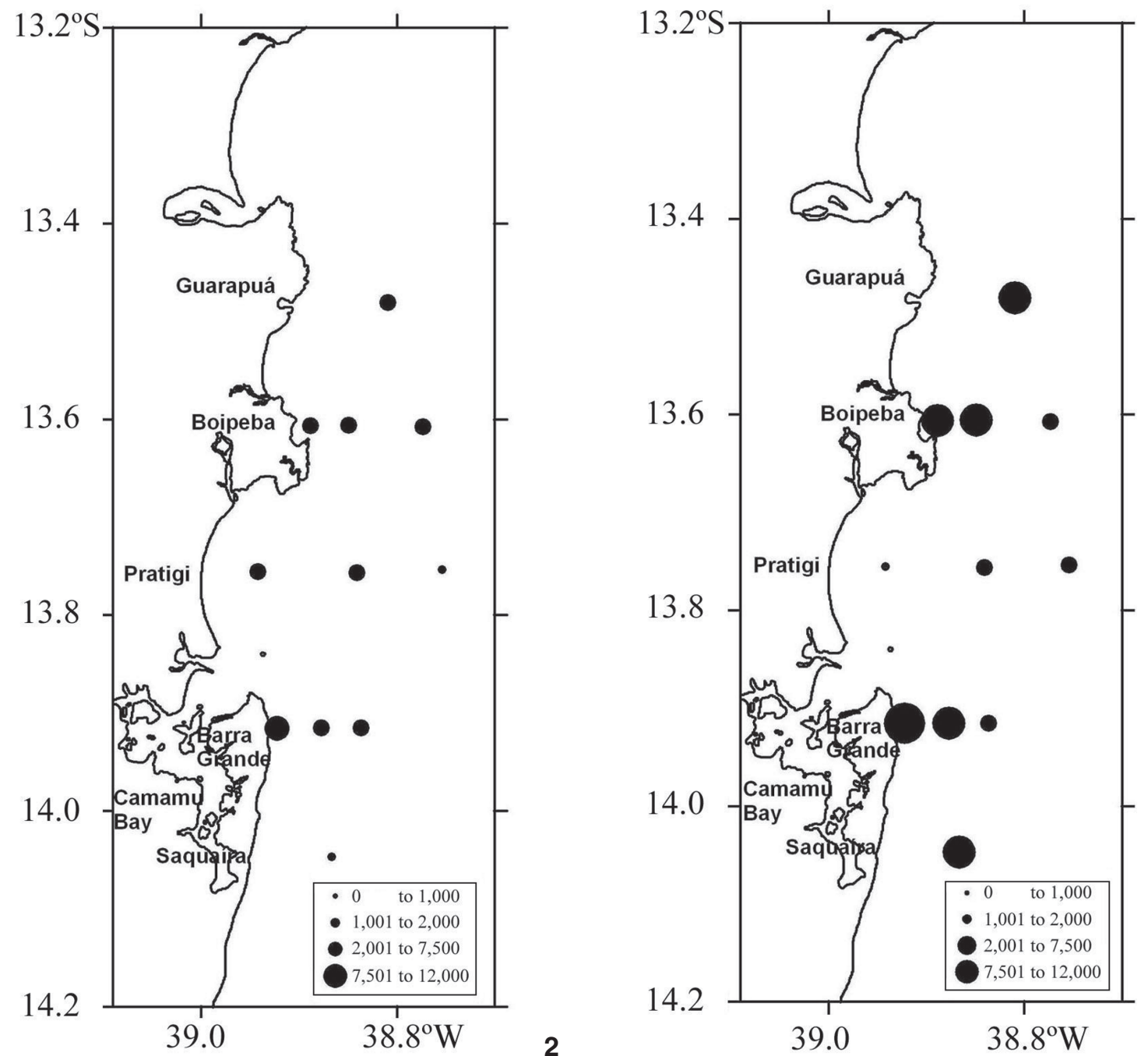

Figures 2-3. Distribution of copepod density (ind. $\mathrm{m}^{-3}$ ) found in two seasons at sampling stations on the inner shelf adjacent to the coastal system of Camamu Bay: (2) wet season, January 2004; (3) dry season, August 2004. 

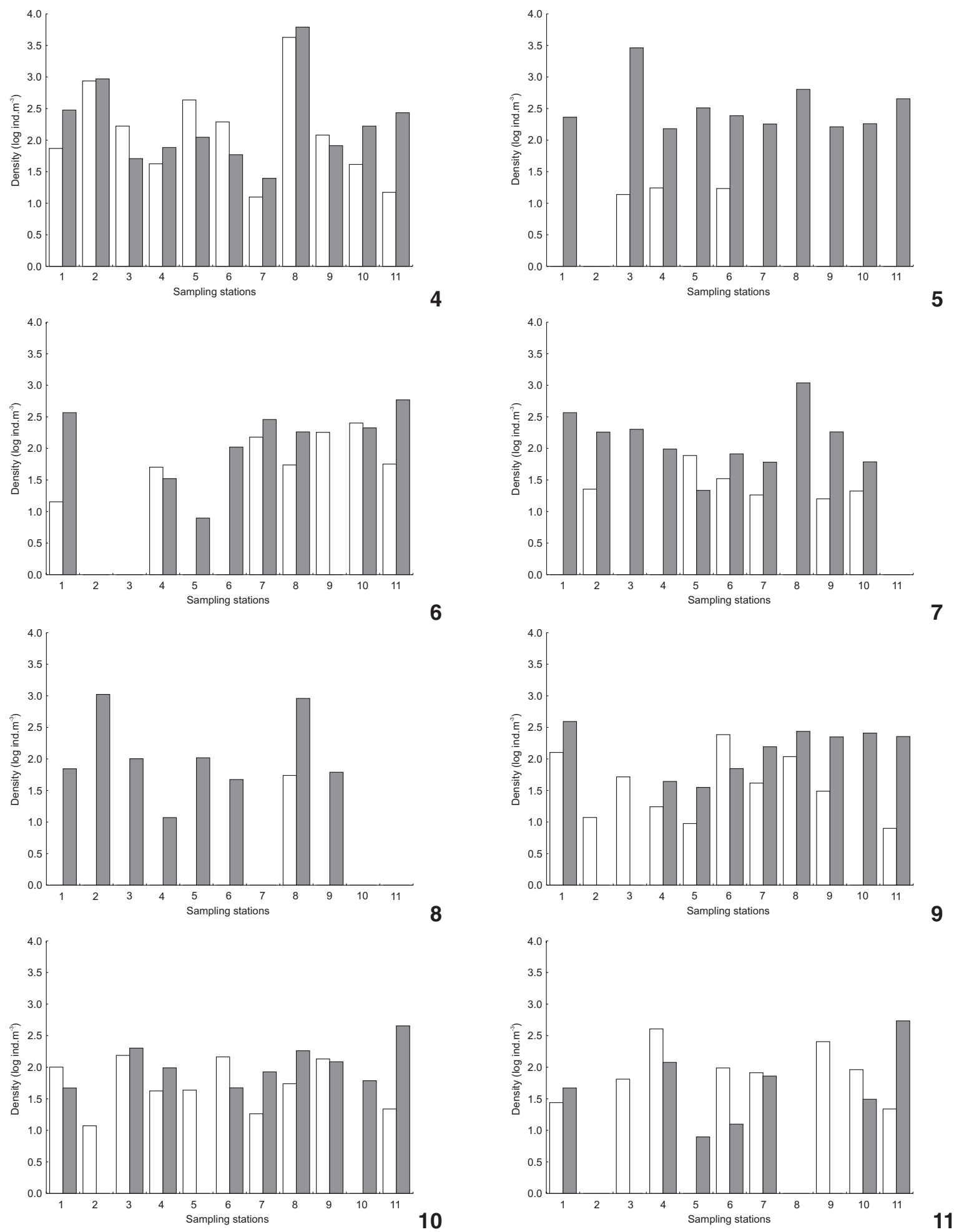

Figures 4-11. Temporal and spatial distribution of copepod density (ind. $\mathrm{m}^{-3}$ ) of the dominant species of copepods on the inner shelf adjacent to the coastal system of Camamu Bay: (4) P. quasimodo; (5) S. pileatus; (6) C. furcatus; (7) C. giesbrechti; (8) T. turbinata; (9) $O$. similis; (10) T. stylifera; (11) N. minor. ( $\square$ ) Wet season; January 2004, (ロ) dry season, August 2004. 
Table II. Minimum (Min.), maximum (Max.), mean, standard deviation (S.D.) (ind. $\mathrm{m}^{-3}$ ), frequency (\%) and occurrence in samples of the copepod taxa sampled in the inner continental shelf adjacent to Camamu Bay.

\begin{tabular}{|c|c|c|c|c|c|c|c|c|c|c|c|c|}
\hline \multirow{2}{*}{ Species/Stations } & \multicolumn{6}{|c|}{ Wet season } & \multicolumn{6}{|c|}{ Dry season } \\
\hline & Min. & Max. & Mean & S.D. & Freq. & Occur. & Min. & Max. & Mean & S.D. & Freq. & Occur. \\
\hline Calanoida & 76.39 & 1827.96 & 335.91 & 504.33 & 18.17 & 11 & 103.96 & 1089.72 & 421.11 & 314.42 & 11.52 & 11 \\
\hline Calanidae & 53.76 & 114.83 & 23.76 & 42.98 & 1.28 & 3 & - & - & - & - & - & - \\
\hline Undinula vulgaris vulgaris & 24.31 & 507.08 & 68.10 & 147.35 & 3.68 & 7 & 11.92 & 405.96 & 87.46 & 120.09 & 2.39 & 7 \\
\hline Nannocalanus minor & 20.83 & 403.79 & 94.23 & 126.07 & 5.10 & 8 & 6.88 & 541.28 & 75.06 & 159.17 & 2.05 & 7 \\
\hline Centropages velificatus & 6.94 & 376.34 & 38.74 & 112.19 & 2.10 & 5 & 45.17 & 299.63 & 109.79 & $86 ; 99$ & 3.00 & 11 \\
\hline Rhincalanus cornutus & 6.63 & 8.24 & 1.35 & 3.03 & 0.07 & 2 & - & - & - & - & - & - \\
\hline Subeucalanus pileatus & 12.76 & 16.48 & 4.12 & 7.12 & 0.22 & 3 & 150.67 & 2896.42 & 495.49 & 813.98 & 13.55 & 10 \\
\hline Subeucalanus sp. & 13.25 & 13.25 & 1.20 & 4.00 & 0.07 & 1 & - & - & - & - & - & - \\
\hline Temora stylifera & 10.82 & 153.11 & 65.28 & 57.20 & 3.53 & 10 & 45.96 & 451.07 & 116.93 & 128.39 & 3.20 & 9 \\
\hline Temora turbinata & 53.76 & 53.76 & 4.89 & 16.21 & 0.26 & 1 & 10.76 & 1052.87 & 213.68 & 382.39 & 5.84 & 8 \\
\hline Acartia lilljeborgi & - & - & - & - & - & - & 20.19 & 120.33 & 12.77 & 36.18 & 0.35 & 2 \\
\hline Acartia sp. & - & - & - & - & - & - & 10.76 & 10.76 & 0.98 & 3.24 & 0.03 & 1 \\
\hline Candaciidae & 8.48 & 20.13 & 7.16 & 7.74 & 0.39 & 6 & 22.98 & 22.98 & 2.09 & 6.93 & 0.06 & 1 \\
\hline Candacia pachydactyla & 12.76 & 12.76 & 1.16 & 3.85 & 0.06 & 1 & - & - & - & - & - & - \\
\hline Clausocalanidae & - & - & - & - & - & - & 90.25 & 90.25 & 8.20 & 27.21 & 0.22 & 1 \\
\hline Clausocalanus furcatus & 13.25 & 251.57 & 68.43 & 86.58 & 3.70 & 7 & 6.88 & 586.39 & 161.42 & 190.67 & 4.41 & 8 \\
\hline Clausocalanus arcuicornis & - & - & - & - & - & - & 10.76 & 135.32 & 15.73 & 40.09 & 0.43 & 4 \\
\hline Mecynocera clausi & 8.48 & 32.21 & 8.12 & 12.53 & 0.44 & 4 & 30.11 & 49.94 & 7.28 & 16.79 & 0.20 & 2 \\
\hline Paracalanus quasimodo & 11.55 & 4247.31 & 563.99 & 1247.62 & 30.50 & 11 & 23.84 & 6175.09 & 749.12 & 1817.94 & 20.49 & 11 \\
\hline Paracalanus aculeatus & 5.78 & 107.53 & 10.30 & 32.29 & 0.56 & 2 & 30.11 & 649.20 & 118.32 & 192.48 & 3.24 & 7 \\
\hline Acrocalanus longicornis & 11.55 & 30.19 & 8.54 & 10.82 & 0.46 & 5 & 30.11 & 30.11 & 2.74 & 9.08 & 0.07 & 1 \\
\hline Calocalanus contractus & 5.78 & 64.41 & 9.93 & 19.19 & 0.54 & 5 & - & - & - & - & - & - \\
\hline Calocalanus pavoninus & 6.94 & 10.06 & 1.55 & 3.51 & 0.08 & 2 & 11.92 & 30.11 & 5.78 & 10.70 & 0.16 & 3 \\
\hline Calocalanus sp. & - & - & - & - & - & - & 10.76 & 10.76 & 0.98 & 3.24 & 0.03 & 1 \\
\hline Lucicutia flavicornis & 16.10 & 16.48 & 2.96 & 6.59 & 0.16 & 2 & - & - & - & - & - & - \\
\hline Pseudodiaptomus acutus & 10.82 & 212.04 & 20.26 & 63.69 & 1.10 & 2 & - & - & - & - & - & - \\
\hline Pleuromamma piseki & 12.76 & 49.44 & 5.65 & 15.02 & 0.31 & 2 & - & - & - & - & - & - \\
\hline Pleuromamma gracilis gracilis & 13.25 & 16.48 & 2.70 & 6.06 & 0.15 & 2 & 45.11 & 45.11 & 4.10 & 13.60 & 0.11 & 1 \\
\hline Pleuromamma sp. & 5.78 & 8.24 & 1.27 & 2.89 & 0.07 & 2 & - & - & - & - & - & - \\
\hline Heterorhabdidae & 6.63 & 6.63 & 0.60 & 2.00 & 0.03 & 1 & 11.92 & 11.92 & 1.08 & 3.59 & 0.03 & 1 \\
\hline Heterorhabdus papilliger & 8.24 & 8.24 & 0.75 & 2.48 & 0.04 & 1 & - & - & - & - & - & - \\
\hline Euchaetidae & 63.55 & 280.70 & 59.51 & 87.32 & 3.22 & 5 & 6.88 & 1353.20 & 325.87 & 520.81 & 8.91 & 9 \\
\hline Euchaeta marina & 8.48 & 561.40 & 151.32 & 208.82 & 8.18 & 8 & 6.88 & 135.32 & 12.93 & 40.65 & 0.35 & 2 \\
\hline Euchaeta paraconcinna & - & - & - & - & - & - & 135.32 & 135.32 & 12.30 & 40.80 & 0.34 & 1 \\
\hline Pontellidae & 13.25 & 13.25 & 1.20 & 4.00 & 0.07 & 1 & - & - & - & - & - & - \\
\hline Calanopia americana & 10.82 & 322.58 & 40.83 & 95.62 & 2.21 & 5 & 20.63 & 749.07 & 114.70 & 221.85 & 3.14 & 6 \\
\hline Pontellopsis brevis & - & - & - & - & - & - & 11.55 & 11.55 & 1.05 & 3.48 & 0.03 & 1 \\
\hline Oithona similis & 6.94 & 241.55 & 58.09 & 73.67 & 3.14 & 10 & 34.39 & 390.63 & 151.67 & 130.89 & 4.15 & 9 \\
\hline Oithona plumifera & 16.10 & 25.52 & 6.10 & 10.72 & 0.33 & 3 & 15.06 & 90.21 & 15.70 & 28.68 & 0.43 & 4 \\
\hline Oithona setigera & 6.63 & 16.10 & 2.07 & 5.06 & 0.11 & 2 & - & - & - & - & - & - \\
\hline Oithona tenuis & 25.52 & 25.52 & 2.32 & 7.69 & 0.13 & 1 & - & - & - & - & - & - \\
\hline Oithona robusta & - & - & - & - & - & - & 40.38 & 40.38 & 3.67 & 12.18 & 0.10 & 1 \\
\hline
\end{tabular}


Table II. Continued.

\begin{tabular}{|c|c|c|c|c|c|c|c|c|c|c|c|c|}
\hline \multirow{2}{*}{ Species/Stations } & \multicolumn{6}{|c|}{ Wet season } & \multicolumn{6}{|c|}{ Dry season } \\
\hline & Min. & Max. & Mean & S.D. & Freq. & Occur. & Min. & Max. & Mean & S.D. & Freq. & Occur. \\
\hline Oncaeidae & 30.19 & 30.19 & 2.74 & 9.10 & 0.15 & 1 & - & - & - & - & - & - \\
\hline Triconia conifera & 8.48 & 16.10 & 2.23 & 5.26 & 0.12 & 2 & - & - & - & - & - & - \\
\hline Oncaea venusta & 8.24 & 193.24 & 62.60 & 59.27 & 3.39 & 11 & 13.76 & 137.87 & 42.21 & 46.16 & 1.15 & 8 \\
\hline Oncaea media & 8.48 & 53.76 & 6.82 & 16.17 & 0.37 & 3 & - & - & - & - & - & - \\
\hline Lubbockia squillimana & - & - & - & - & - & - & 11.92 & 11.92 & 1.08 & 3.59 & 0.03 & 1 \\
\hline Corycaeidae & 10.42 & 10.42 & 0.95 & 3.14 & 0.05 & 1 & 43.05 & 43.05 & 3.91 & 12.98 & 0.11 & 1 \\
\hline Farranula gracilis & 5.78 & 120.75 & 33.90 & 50.25 & 1.83 & 6 & 11.55 & 270.64 & 49.36 & 80.96 & 1.35 & 7 \\
\hline Corycaeus giesbrechti & 14.91 & 76.34 & 16.60 & 22.87 & 0.90 & 6 & 20.63 & 1089.722 & 212.50 & 309.03 & 5.81 & 10 \\
\hline Corycaeus speciosus & 5.78 & 65.93 & 19.03 & 24.27 & 1.03 & 6 & 6.88 & 83.43 & 15.77 & 29.03 & 0.43 & 4 \\
\hline Corycaeus limbatus & 5.78 & 16.10 & 3.19 & 5.97 & 0.17 & 3 & 45.11 & 45.11 & 4.10 & 13.60 & 0.11 & 1 \\
\hline Sapphirinidae & 10.06 & 10.06 & 0.91 & 3.00 & 0.05 & 1 & - & - & - & - & - & - \\
\hline Macrosetella gracilis & 6.63 & 74.57 & 17.60 & 27.10 & 0.95 & 5 & 11.92 & 11.92 & 1.08 & 3.59 & 0.03 & 1 \\
\hline Oculosetella gracilis & 14.91 & 14.91 & 1.36 & 4,50 & 0.07 & 1 & - & - & - & - & - & - \\
\hline Euterpina acutifrons & 10.82 & 53.76 & 5.87 & 16.21 & 0.32 & 2 & 13.76 & 90.81 & 9.51 & 27.28 & 0.26 & 2 \\
\hline Monstrilloida & 0.10 & 0.10 & 0.01 & 0.03 & 0.001 & 1 & 0.23 & 0.23 & 0.02 & 0.07 & $<0.01$ & 1 \\
\hline
\end{tabular}

In the wet season, 36 species were found. The assemblage was dominated by eight species: P. quasimodo, Euchaeta marina (Prestandrea, 1833), N. minor, C. furcatus, Undinula vulgaris vulgaris (Dana, 1849), T. stylifera, Oncaea venusta Philipp, 1843 and O. similis. The genera Paracalanus and Temora dominated, accounting for $36 \%$ of the total copepod abundance (Tab. II). Paracalanus quasimodo was the most dominant species in the coastal system, constituting $31 \%$ of the total copepod abundance. This species was the dominant estuarine-coastal copepod at the stations located on the 10-m isobath (stations 2, 5, and 8). Another estuarine-coastal species, Calanopia americana F. Dahl, 1894, was abundant at station 11, on the 30-m isobath. The marine-euryhaline $C$. furcatus was abundant at stations located on the 50-m isobath (stations 7 and 10), E. marina on the 30-m isobath (stations $1,3,6$ ), and $N$. minor at the $30-\mathrm{m}$ isobath (station 9) and the 50-m isobath (station 4). Other marine-euryhaline copepods such as $U$. vulgaris vulgaris, O. similis, O. venusta and T. stylifera were abundant at stations located along the 30-m isobath.

In the dry season, fewer species (30) were recorded. This assemblage was dominated by $P$. quasimodo, which comprised up to $20 \%$ of the total copepod abundance, followed by $T$. turbinata, C. giesbrechti, S. pileatus, C. furcatus, O. similis, Paracalanus aculeatus Giesbrecht, 1888, T. stylifera, C. americana and Centropages velificatus (Oliveira, 1947), representing more than $76 \%$ of the total copepod numbers (Tab. II). The family Paracalanidae occurred at all 11 sampling stations. Paracalanus quasimodo and T. turbinata were mainly abundant at stations 8 (near Barra Grande) and 2 (near Boipeba) located on the 10-m isobath. Subeucalanus pileatus was abundant at stations 3 to 6 on the Boipeba and Pratigi transects located north of Camamu Bay. Clausocalanus furcatus was abundant at the 30-m (station 11) and 50-m (station 7) isobaths. Oithona similis was abundant at the stations on the 30-m (station 1) and 50-m (stations 9 and 10) isobaths. Other copepods such as C. americana (estuarine-coastal), T. stylifera, C. velificatus (coastal-marine), and $P$. aculeatus (marine-euryhaline) were abundant at the stations along the 30-m isobath. The marine-euryhaline C. giesbrechti was abundant along the 10-m isobath.

Cluster analysis indicated the formation of station groups in both cruises, at a 55\% similarity level. The spatial distribution of these groups indicated three, clearly separated faunistic areas: A) comprising the samples located at the isobaths of 10 $\mathrm{m}$ (stations 2, 5) and $30 \mathrm{~m}$ (stations 3, 6) near the entrance of Camamu Bay, during the wet season; B) comprising the samples located at the isobaths of 30 (stations 1, 9 and 11) and $50 \mathrm{~m}$ (stations 4, 7 and 10), during the wet season; and C) comprising the samples collected during the dry season, mainly (Fig. 12). Multi-dimensional scaling was used in order to reveal if species density variation was an important factor determining changes in the copepod assemblage. Results from pairwise tests of ANOSIM for the sampling periods demonstrated that samples that were separated by different copepod assemblages were all significantly different from each other (significance level of sample statistic $=0.1 \%$ and global $\mathrm{R}=0.77$ ).

The group A assemblage encompassed the stations located near the entrance of Camamu Bay at the 10- and 30-m isobaths, during the wet season. This had the lowest salinities (30.7) and high temperatures $\left(>27^{\circ} \mathrm{C}\right)$, at the surface, which is mainly characteristic of the CW. Eight species accounted for 


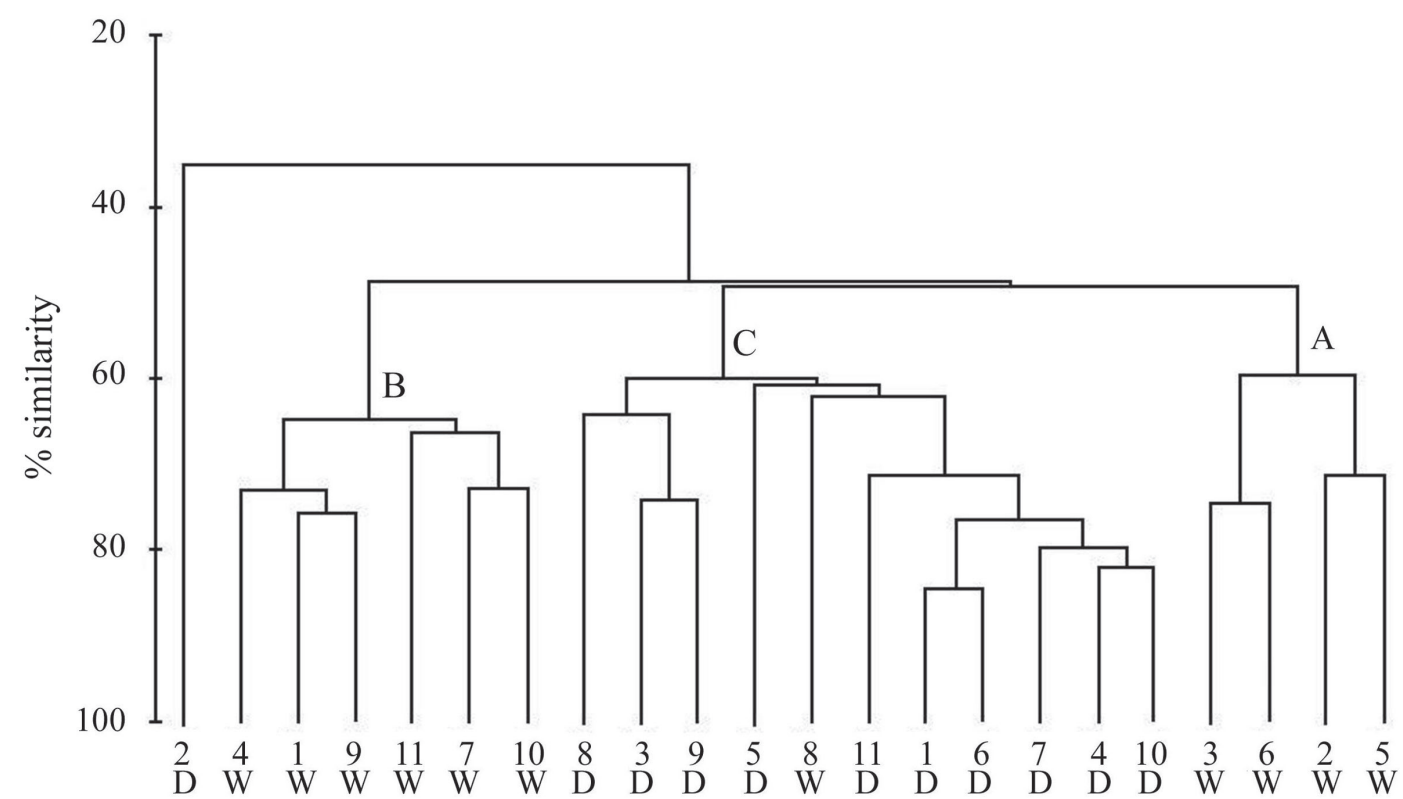

Figure 12. Cluster analysis performed for samples-species data matrixes of the two seasons in sampling stations on the inner shelf adjacent to Camamu Bay.

$89 \%$ of the similarity in this group (Simper test), namely $P$. quasimodo (22\%); O. venusta, T. stylifera and E. marina (13\%); O. similis (10\%); C. giesbrechti (77\%); and Oithona plumifera Baird, 1843 and C. velificatus (5\%).

Group B consisted of stations located on the inner shelf (30- and 50-m isobaths) adjacent to Camamu Bay, during the wet season. In this area, the MW and TW affected the water conditions. C. furcatus (13\%), P. quasimodo and O. venusta (11\%), N. minor (10\%), U. vulgaris vulgaris and T. stylifera (9\%), O. similis and Farranula gracilis (Dana, 1849) (7\%), and Corycaeus speciosus Dana, 1849 and Macrosetella gracilis (Dana, 1847) (5\%) were the main species responsible for the delimitation of this group of stations, accounting for $82 \%$ of internal similarities. During the wet season, temperatures (surface $r=-0.45$, and near the bottom $\mathrm{r}=-0.37$; $\mathrm{p}<0.005)$ were negatively correlated with density.

In station group $\mathrm{C}$, the samples were collected during the dry season, with the occurrence of the MW and TW during the flood tide at all sampling stations. Temperature $(\mathrm{r}=0.70 ; \mathrm{p}$ $<0.005)$ and salinity $(\mathrm{r}=0.78 ; \mathrm{p}<0.005)$ near the bottom were significantly correlated with density, reflecting the pattern of occurrence of the highest temperatures and salinity in the dry season. Twelve species accounted for $84 \%$ of similarity in this group, namely S. pileatus (14\%); P. quasimodo and C. velificatus (11\%); O. similis, C. giesbrechti and T. stylifera (9\%); C. furcatus (6\%); O. venusta, T. turbinata and P. aculeatus (5\%); U. vulgaris vulgaris (4\%) and N. minor (3\%).

The copepods on the inner shelf adjacent to Camamu Bay can be classified according to their habitat, as follows.
Estuarine-coastal assemblage: these species are adapted to a wide temperature range and low-salinity waters. Only a few species typical of this assemblage were found in these waters. Representative species included Acartia lilljeborgi Giesbrecht, 1889, P. quasimodo, Pseudodiaptomus acutus (F. Dahl, 1894), C. americana and Euterpina acutifrons (Dana, 1847).

Coastal-tropical assemblage: C. furcatus, T. stylifera, T. turbinata, O. similis, O. plumifera, Oithona setigera Dana, 1852, Oithona tenuis Rosendorn, 1917 and Oithona robusta Giesbrecht, 1891 were classified in this case. With the exception of $C$. furcatus, $T$. stylifera and T. turbinata, the other species occurred in low frequency and abundance in one of the cruises (wet or dry season).

Tropical assemblage: species such as $U$. vulgaris vulgaris, $N$. minor, S. pileatus, Rhincalanus cornutus (Dana, 1849), Candacia pachydactyla (Dana, 1849), C. furcatus, Clausocalanus arcuicornis (Dana, 1849), Mecynocera clausi Thompson I.C., 1888, P. aculeatus, Acrocalanus longicornis Giesbrecht, 1888, Calocalanus contractus Farran, 1926, Calocalanus pavoninus Farran, 1936, Lucicutia flavicornis (Claus, 1863), Pleuromamma piseki Farran, 1929, Pleuromamma gracilis gracilis (Claus, 1863), Heterorhabdus papilliger (Claus, 1863), E. marina, Euchaeta paraconcinna Fleminger, 1957, Pontellopsis brevis (Giesbrecht, 1889), O. venusta, Triconia conifera (Giesbrecht, 1891), Oncaea media Giesbrecht, 1891, Lubbockia squillimana Claus, 1863, F. gracilis, C. giesbrechti, Corycaeus speciosus Dana, 1849, Corycaeus limbatus Brady, 1883, Macrosetella gracilis (Dana, 1847) and Oculosetella gracilis (Dana, 1849) occurred mainly in the wet season with high water temperatures. The record of E. paraconcinna is a new occurrence for the northeast coast of Brazil (DiAs \& BONECKER 2006). 
Copepod taxa richness showed fluctuations. Species richness ranged from 10 at station 2 to 16 at stations 3, 4, 6 and 7 in the wet season, and from 6 at station 2 to 18 at station 10 in the dry season (Fig. 13). In general, species richness was highest at the stations on the 30- and 50-m isobaths. The diversity index $\left(\mathrm{H}^{\prime}\right)$ varied between 1.21 at station 2 (10-m isobath) to 3.61 at station 11 (30-m isobath) in the wet season, and between 1.88 at station $8(10-\mathrm{m}$ isobath) to 3.75 at station 11 (30-m isobath) in the dry season. The diversity index at station 11 in the cruises was high, and more species were recorded at this station than at the other stations. The lowest evenness $(\mathrm{J})$ ( 0.36 in the wet season and 0.59 in the dry season) was found at stations 2 and 8 located on the 10-m isobath), and the highest evenness (0.92 in the wet season and 0.93 in the dry season) was recorded at stations 11 (30-m isobath) and 4 (50-m isobath). Both species richness and diversity increased on the inner shelf adjacent to Camamu Bay at the 30- and 50-m isobaths in both sampling periods, suggesting that most species were oceanic in origin.

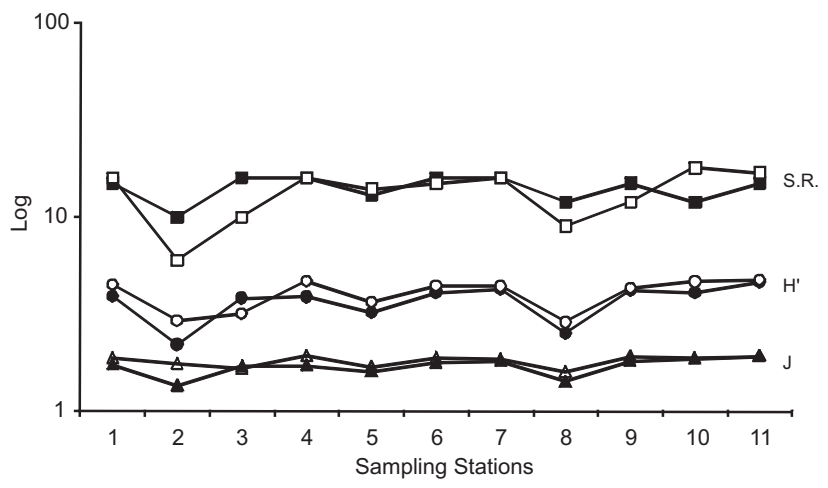

Figure 13. Species richness (SR), diversity index $\left(\mathrm{H}^{\prime}\right)$ and evenness (J) of the two seasons in sampling stations on the inner shelf adjacent to Camamu Bay: ( $\mathbf{\square})$ SR, wet season, $(\square)$ SR, dry season, ( $)$ $\mathrm{H}^{\prime}$, wet season, $(\bigcirc) \mathrm{H}^{\prime}$, dry season, $(\boldsymbol{\Delta}) \mathrm{J}$, wet season, $(\triangle) \mathrm{J}$, dry season.

\section{DISCUSSION}

Camamu Bay is located on the northeast coast of Brazil, where it is influenced by the warm, nutrient-poor water of the Brazil Current (BRANDINI et al. 1997). Water from several rivers reduces the salinity and the natural eutrophication of the bay. The shelf and open ocean off northeast Brazil is largely affected by two water masses: the Tropical (TW) and the South Atlantic Central Waters (SACW) (NeUMANN-Leitão et al. 1999). In this study, the continental influence was evidenced in the wet season. The Coastal Water (CW) of Camamu Bay was observed over the continental shelf during the wet season. The continental influence on the spatial distribution of salinity was evi- denced by the presence of the Mixed Water (MW), during the dry season. In this sampling period, the MW dominated at the surface and the TW near the bottom. The continental influence was more evident during the wet season, perhaps because all the sampling was carried during flood tide. The MW and TW were recorded at the surface and near the bottom in the wet season as well. The SACW was not recorded in this study: water temperature remained high $\left(>24.4^{\circ} \mathrm{C}\right)$.

On the inner continental shelf adjacent to the coastal system of Camamu Bay, significant temporal differences were observed between the two cruises. Copepod abundance was higher in the dry than in the wet season. Environmental stability, characterized by slight variation in salinity and temperature, was correlated with the higher abundance during the dry season, with the presence of the MW and TW in the region.

As was expected, in both cruises, the density of copepods as a function of depth separated the stations. In both cruises, station 8 (near Barra Grande) showed the highest density. This station was located near the entrance of Camamu Bay, at the $10-\mathrm{m}$ isobath. The lowest densities were recorded at stations along the 30- and 50-m isobaths. The highest densities observed in the bay and at the $10-\mathrm{m}$ isobath reflect the typical coastocean gradient observed on the Brazilian coast and on coasts worldwide. The bay and coastal region are enriched by continental outflow from rivers and leaching during flood tide, which provide nutrients to the marine ecosystem. These nutrients increase productivity in the system through growth of phytoplankton, which in turn favors the majority of the species of mesozooplankton, which typically are herbivores or omnivores (NYBAKKEN \& BERTNESS 2005).

Copepods were the dominant zooplankters in the study area. The majority of the copepod species found in this study are typical for the TW (69\%), mainly in the dry season and at flood tide. Björnberg (1981) and Bradford-Grieve et al. (1999) described this dominance in TW in the Southwest Atlantic.

The dominance of the copepods changed between the cruises, and it was influenced by the water masses present in the area. The copepod assemblage contained a mixture of neritic and oceanic species. Only the estuarine-coastal P. quasimodo, the coastal-tropical $T$. stylifera and $O$. similis, and the tropical C. furcatus were abundant during both cruises (wet and dry seasons). Some species showed a clear seasonal distribution, according to temperature and salinity range. For instance, $S$. pileatus, T. turbinata, C. americana, C. velificatus and $P$. aculeatus were all more abundant during the dry season. Some cold-water species occurred in the area, although the South Atlantic Central Water (SACW) was not observed in the region during the sampling period. Species such as $H$. papilliger, typical of the SACW, occurred in low abundance at a station on the $50-\mathrm{m}$ isobath during the wet season. The presence of this species during this season may indicate that it penetrates onto the shelf only during an upwelling period, and disappears after the upwelled water warms. This process was observed off Cabo Frio 
on the coast of Rio de Janeiro, Brazil, by Lopes et al. (1999).

Temora turbinata is a marine-euryhaline species that occurs mostly in areas with high salinities (Lopes et al. 1998). It is an introduced species in Brazilian coastal waters, and the first record was reported by Araújo \& MonTú (1993) in the estuarine region of northeast Brazil. MuXaGATA \& GLOEDEN (1995), Lopes et al. (1999) and SCHUTZE \& BJÖRNBERG (2002) recorded this species in south, southeast and northeast Brazil. The replacement of the native species $T$. stylifera by the T. turbinata on the Brazilian coast was described by ArA (2002). Also according to this author, the high production of $T$. turbinata (P/B ratio) explains its greater abundance in relation to the native species.

A distinct range of thermohaline requirements was associated with the occurrence of the two species of Temora. Temora turbinata occurred during the wet season, at only one station located south of Camamu Bay. This species occurred in higher concentrations (> 900 ind. $\mathrm{m}^{-3}$ ), with low ranges both of temperature $\left(25.0-26.3^{\circ} \mathrm{C}\right)$ and salinity $(35.3-35.5)$ in the MW. Temora stylifera occurred in both sampling periods, with low densities $\left(<500\right.$ ind. $\left.\mathrm{m}^{-3}\right)$ in all three water masses. The seasonal occurrence of these species may represent a strategy to favor their coexistence. The lower tolerance of $T$. stylifera to variations in salinity, compared with $T$. turbinata, makes it less competitive in coastal and estuarine waters than the invasive species. This coexistence has been reported in other regions along the Brazilian coast (EsKINAZI-SANT'ANNA \& BJÖRNBERg 2006, RESGALLA JR et al. 2008).

The new occurrence of E. paraconcinna in the area is only the second record in Brazilian waters; the species was previously recorded off northern Brazil (state of Maranhão). Euchaeta paraconcinna has a tropical-subtropical distribution and mesopelagic habit (DIAS \& BONECKER 2006). In the study area, it occurred to the south on the adjacent inner shelf near Camamu Bay, at the 30-m isobath.

The local copepod assemblage is characterized by high biodiversity at the stations located on the 30- and 50-m isobaths, with high densities occurring during the dry season mainly at the stations located on the 10-m isobaths. The copepod assemblage on the inner continental shelf adjacent to the coastal system of Camamu Bay showed a prevalence of the same species as those which occur in the main tropical coastal waters off the Brazilian coast (Neumann-Leitão et al. 1999, EskinaZI-SANT'ANNA \& BJÖRnBERg 2006). The dominant copepod $P$. quasimodo is an estuarine-coastal species which is common on the Brazilian southeastern coast (STERza \& Loureiro Fernandes 2006, Dias \& Bonecker $2008 \mathrm{a}, \mathrm{b})$. The narrow shelf allows interaction between the coastal and oceanic communities, which are influenced by the environmental parameters of temperature and salinity.

\section{ACKNOWLEDGMENTS}

This study was conducted in the Integrated Laboratory of Zooplankton and Ichthyoplankton, Department of Zoology, Institute of Biology, Federal University of Rio de Janeiro (UFRJ) as part of a monitoring program of Camamu Bay developed by
ENSR International do Brasil Ltda and Kriteria Consultores Associados Ltda. We thank the El Paso Óleo and Gás do Brasil Ltda for placing some of their zooplankton material at our disposal. We also thank an anonymous reviewer, whose helpful comments resulted in improvements to the paper. Dr. Janet W. Reid revised the English text.

\section{LITERATURE CITED}

ARA, K. 2002. Temporal variability and production of Temora turbinata (Copepoda: Calanoida) in the Cananéia Lagoon estuarine system, São Paulo, Brazil. Scientia Marina 66 (4): 399-406.

Araújo, H. \& M. Montú. 1993. Novo registro de Temora turbinata (Dana, 1949) (Copepoda, Crustacea) para águas atlânticas. Nauplius 1: 89-90.

Berasategui, A.D.; S. Menu Marque; M. Gomez-Erache; F.C. Ramírez; H.W. Mianzan \& E.M. Acha. 2006. Copepod assemblages in a highly complex hydrographic region. Estuarine, Coastal and Shelf Science 66: 483-492.

BJöRNBERG, T.K.S. 1963. On the marine free-living copepods off Brazil. Boletim do Instituto Oceanográfico 13 (1): 3-142.

BJöRnBERG, T.K.S. 1981. Copepoda, p: 587-679. In: D. BoltovskoY (Ed.). Atlas del Zooplancton del Atlántico Sudoccidental y métodos de trabajo com el zooplancton marino. Mar del Plata, INIDEP, 936p.

Bradford-Grieve, J.M.; E.I. Markhaseva; C.E.F. Rocha \& B. Abiahy. 1999. Copepoda, p. 869-1098. In: D. Boltovskoy (Ed.). South Atlantic Zooplankton. Leiden, Backhuys Publishers, 1706p.

Brandini, F.P.; R.M. Lopes; K.S. Gutseit; H.L. SPach \& R. SASI. 1997. Planctonologia na plataforma continental do Brasil Diagnose e revisão bibliográfica. Curitiba, MMA/CIRM/ FEMAR, 196p.

Clarke, K.R. \& R.M. Warwick. 1994. Changes in marine communities: an approach to statistical analysis and interpretation. Plymouth, Plymouth Marine Laboratory, Natural Environment Research Council, UK, 144 p.

De Oliveira, O.M.C.; A.F. de S. QueIroz \& J.L. Argolo. 2002. Estudo mineralógico do sedimento de manguezal da baía de Camamu-Ba. Revista Escola de Minas 55 (2): 147-151.

Dias, C.O. \& A.V. Araujo. 2006. Copepoda, p. 21-99. In: S.L.C. BONECKER (Ed.). Atlas do zooplâncton da região central da Zona Econômica Exclusiva. Rio de Janeiro, Museu Nacional, Série Livros/Documentos Revizee Score Central 21, 228p.

DiAs, C.O. \& S.L.C. BONECKER. 2006. Occurrence of Euchaeta paraconcinna Fleminger, 1957 (Crustacea, Copepoda, Calanoida) in a coastal area of Bahia State, northeastern Brazil. Biota Neotropica 6: 305-307. Available online at: http://www.biotaneotropica.org.br/v6n 3/en / fullpaper?bn02406032006+pt [Accessed: 16/IV/2009].

DiAs, C.O. \& S.L.C. BONECKER. 2007. New records of Monstrilloida Sars, 1901 (Crustacea, Copepoda) on the Brazilian Northeastern coast. Biota Neotropica 7: 281-285. Available online at: http://www.biotaneotropica.org.br/v7n2/pt/abstract? 
short-communication+bn00407022007 [Accessed: 16/IV/ 2009].

Dias, C.O. \& S.L.C. Bonecker. 2008a. Long-term study of zooplankton in the estuarine system of Ribeira Bay, near a power plant (Rio de Janeiro, Brazil). Hydrobiologia 614: 65-81.

DiAS, C.O. \& S.L.C. BONECKER. 2008b. Inter-annual Variability of Planktonic Copepods in a Tropical Bay in Southeastern Brazil. Brazilian Archives of Biology and Technology 51: 731-742.

Eskinazi-SANT'ANNA, E.M. \& T.K.S. BJÖRnberg. 2006. Seasonal dynamics of mesozooplankton in Brazilian coastal waters. Hydrobiologia 563: 253-268.

Frontier, S. 1981. Cálculo del error en el recuento de organismos zooplanctónicos, p. 163-167. In: D. Boltovskoy (Ed.). Atlas del Zooplancton del Atlántico Sudoccidental y métodos de trabajo com el zooplancton marino. Mar del Plata, INIDEP, 936p.

Gaudy, R. 1963. Campagne du naviere oceanographique "Calypso" dans les eaux cotiers du Brésil (Janvier-Fevrier, 1962): Copepodes pelagiques. Recueil des Travaux de la Station Marine d'Endoume 30 (45): 15-42.

Lopes, R.M.; R. DO VALE \& F.P. BRANDini. 1998. Composição, abundância e distribuição espacial do zooplâncton no complexo estuarino de Paranaguá durante o inverno de 1993 e o verão de 1994. Revista Brasileira de Oceanografia 46: 195-211.

Lopes, R.M.; F.P. Brandini \& S.A. Gaeta. 1999. Distribution patterns of epipelagic copepods off Rio de Janeiro (SE Brazil) in summer 1991/1992 and winter 1992. Hydrobiologia 411: 161-174.

Lima, W. S.; C.L.C. Manso \& E.J. Andrade. 2003. Bacias sedimentares brasileiras: Bacia de Camamu. Phoenix 54: 1-6.

Madureira, L.S.P.; R.P. Habiaga; A. Gonçalves; A.B. Greig; A.C. Duvoisin; C.F. Soares; I.Y. Fuse; F.G. Caldeira; L.R. Carvalho; S.C. Weigert; P.A. Saldo \& C.S. Ferreira. 2004. Prospecção de recursos pelágicos por método hidroacústico na plataforma, talude e região oceânica da costa Central do Brasil. São Paulo, Instituto Oceanográfico, USP, Série Documentos Revizee - Score Sul, 56p.

McEwen, G.F.; M.W. Johnson \& T.R. Folsom. 1957. A statistical analysis of the performance of the Folsom plankton sample splitter, based upon test observations. Archives for Meteorology Geophysics and Bioclimatology 7: 502-527.

Milani, E.J.; J.A.S.L. BRandão \& P.V. Zalan. 2000. Petroleum in the brazilian continental margin: geology, exploration, results and perspectives. Revista Brasileira de Geofísica 18 (3): 352-396.

Muxagata, E. \& I.M. Gloeden. 1995. Ocorrência de Temora turbinata Dana, 1949 (Crustacea: Copepoda) no estuário da Lagoa dos Patos, RS, Brasil. Nauplius 3: 163-164.
NeUMANN-Leitão, S. 1994/1995. Resenha literária sobre zooplâncton estuarino no Brasil. Trabalhos de Oceanografia da Universidade Federal 23: 25-53.

Neumann-Leitão, S.; L.M. DE O. Gusmão; T. de A. Silva; D.A. de Nascimento-Vieira \& A.P. Silva. 1999. Mesozooplankton biomass and diversity in coastal and oceanic waters off North-eastern Brazil. Archive of Fishery and Marine Research 47 (2/3): 153-165.

Nybakken, J.W. \& M.D. Bertness. 2005. Marine Biology. An ecological approach. San Francisco, Benjamin Cummings, 579p.

Peixinho, V.M.C.; J.F. Paredes \& E.M.P. Simas. 1980. "Standing crop" na área estuarina sudoeste da Baía de Todos os Santos. Boletim do Instituto oceanográfico 29 (2): 283-289.

Pielou, E.C. 1977. Mathematical Ecology. New York, John Wiley, 385p.

Resgalla Jr, C.; V.G.C de Souza; L.R. Rörig \& C.A.F. Schettini. 2008. Spatial and temporal variation of the zooplankton community in the area of influence of the Itajaí-Açu River, SC (Brasil). Brazilian Journal of Oceanography 56 (3): 211-224.

Santos, J.J. 1973. Estudo preliminar, principalmente do plâncton, das águas da Baía de Todos os Santos. Boletim de Zoologia e Biologia Marinha 30: 419-447.

SchutZe, M.L.M. \& T.K.S. BJöRnBerg. 2002. Population structure of Temora stylifera (Dana. 1849) (Copepoda) off Ipanema and in Gunabara Bay (Rio de Janeiro, Brazil) from February 83 to January 84. Nauplius 10 (2): 83-95.

Schwamborn, R. \& A.C.T. Bonecker. 1996. Seasonal changes in the transport and distribution of meroplankton into a Brazilian estuary with emphasis on the importance of floating mangrove leaves. Brazilian Archives of Biology and Technology 39 (2): 451-462.

Seguin, G. 1965. Contribution à la connaissance du plancton des eaux cotières du Brésil (copépodes et amphipodes excepts) et comparaison avec celui du Sénégal (Campagne de la Calypso, Janv. - Feb. 1962). Pelagos 2 (3): 7-44.

SHANNON, C.E. 1948. A mathematical theory of communication. Bell System Technical Journal 27: 379-423.

Souza, T.C.M. \& M. Petrere-Jr. 2008. Characterization of smallscale fisheries in the Camamu-Almada basin, southeast state of Bahia, Brazil. Brazilian Journal of Biology 68 (4): 711719.

Sterza, J.M. \& L. Loureiro Fernandes. 2006. Zooplankton community of the Vitória bay estuarine system (southeastern Brazil). Characterization during a three-year study. Brazilian Journal of Oceanography 54: 95-105.

Valentin, J.L. \& W.M. Monteiro-Ribas. 1993. Zooplankton community structure on the east-southeast Brazilian continental shelf (18-23 ${ }^{\circ}$ latitude). Continental Shelf Research 13 (4): 407-424.

Submitted: 18.I.2009; Accepted: 23.XI.2009.

Editorial responsibility: Paula da Cunha Lana

ZOOLOGIA 26 (4): 629-640, December, 2009 